\title{
資料
}

\section{ヘルシンキ宣言南ア改訂版・WFAS 倫理コード・日本鍼炎師会倫理コード}

全日本鍼尒学会常務理事・国際部長

全日本鍼炎学会常務理事・編集部長

全日本鍼炎学会参与・世界鍼炎学会連合会 $($ WFAS ) 副会長
津谷喜一郎

尾崎 昭弘

黒須 幸男

\section{まえがき}

本稿では、鍼炎の治療や研究の倫理に関連する 3つの資料を紹介する。

第 1 は、最新版のヘルシンキ宣言である。原文 と日本語訳を収載する。1996年10月、南アフリカ 共和国のサマーセットウエストで行われた世界医 師会の第48回総会で、ヘルシンキ宣言第 II 章の「専 門職としてのケアと結びついた医学研究（臨床研 究)」の 3 項の一部追加修正が行われた。

3 項には、これまで「いかなる医学研究におい ても、どの患者も一対照群があればそれを含めて一 現行の最善と証明されている診断法および治療法 を受けることができるという保証が与えられなけ ればならない。(ヘルシンキ宣言. 全日本鍼炎学 会雑誌 $1997 ； 46$ (3)：174-179）とされていた。 今回、本項に「これは、立証された診断法あるい は治療法が存在しない場合の研究における無作用 プラシーボの使用を除外するものではない」(This does not exclude the use of inert placebo in studies where no proven diagnostic or therapeutic method exists.) という一文が追加 された。これによって対照群にプラシーボを用い ることの倫理的正当性がこれまでよりも明確になっ た。

今回のヘルシンキ宣言の一部追加修正の背景や、 これを引き継ぐ GCP (Good Clinical Practice、 医薬品の臨床試験の実施に関する基準) などの動 きについては、下記の文献が参考となろう。

(1) Annas GL, Grodin MA (ed.). The Nazi doctors and the Nuremberg Code - Human rights in human experimentation. New York: Oxford University Press, 1992

（2）光石忠敬。個々の被験者や患者の自由と安全 にとってヘルシンキ宣言の1975年改訂とは何か. 臨床評価 $1976 ； 4(1): 155-164$

（3）光石忠敬. 共同作業への参加の証としてのイ ンフォームド・コンセント一臨床試験と人権に ついて考える一。臨床評価 1988 ；16(4)：569580

(4) International ethical guidelines for biomedical research involving human subjects-Prepared by the Council for International Organizations of Medical Sciences (CIOMS) in collaboration with the World Health Organization (WHO). Geneva: CIOMS, 1993 [光石忠敬 (訳). 被験者に対する 生物医学研究についての国際的倫理指針。臨床 評価 $1994 ; 22(2,3)$ : 261-297]

（5）坂上正道、長澤俊彦、光石忠敬、津谷喜一郎. 座談会・臨床試験とバイオエシックス.からだ の科学 $1997 ; 196: 2-15$

（6）厚生省. 医薬品の臨床試験の実施の基準に関 する省令、他. 臨床評価 1997 ; 25, Supplement No. XII : 1-228 [日本の新 GCPは、薬事法、省 令、局長通知、課長通知などから、群として成 り立っていてわかりずらいが、このうち1997年 5 月29日付けの課長通知に別添として添付され た中央薬事審議会答申が、日米欧の 3 極で1996 年 5 月 1 日に合意された $\mathrm{ICH}-\mathrm{GCP} に$ 近いもの 
である]

( 7 ) Tsutani K. General view of clinical trials and GCP in East Asia. Drug Information Journal1997；31(4)：1057-1064［この雑誌は、 インターネット上でも見ることができる(http：// www.diahome.org/dhp5a5a7.htm)。日中韓台 シンガポールなどからの参加者による興味深い パネル・ディスカッションもここで見られる］

第 2 は、世界鍼尒学会連合会 (WFAS) 倫理コー ドである。原文と日本語訳を収載する。これは 1987 年11月22日の北京での WFAS 設立総会で、“Code of Ethics of the World Federation of Acupuncture-Moxibustion Societies (WFAS)" (世界鍼炎学会連合会倫理コード)として採択され たものである。本倫理コードの作成は、(社)全日 本鍼炎学会の前会長であった故・高木健太郎氏の 発案によるもので、その後の作業プロセスは、以 下の文献に詳しい。

津谷喜一郎. WHO と伝統医学 (12) - 保健分野 のパートナーとしての $\mathrm{NGO}$ - (その 3 ). 現代東 洋医学 $1993 ; 14(4): 591-605$

本倫理コードの存在は、あまり日本で知られて いない。全日本銊炎学会は、WFASの設置にも深 く関わり、現在でも有力メンバーの一つである。 本倫理コードのより広い認知が望まれる。

なお、昨年1996年10月31日にニューヨークで開 催されたWFAS代議員総会で、従来の法制委員会 (Legislation Committee)、教育委員会(Education Committee)、資格審査委員会（Qualification Examination Committee、WFAS 加盟を希望す る学協会について審査する委員会)、財務委員会 (Financial Committee)、学術委員会 (Academic Committee) の 5 つの作業委員会の他に、新たに 倫理綱領委員会 (Code of Ethics Committee、 委員長：黑須幸男）と国際鍼炎師水準考試委員会 (International Acupuncturist Proficiency Examination Committee) が設置された。

現在のWFAS倫理コードの第10項目に記される ヘルシンキ宣言は、1983年のベニス改訂版までし
かカバーしておらず、この新しくスタートしたWFAS 倫理綱領委員会は、1987年の香港と、1996年の南 アフリカ・サマーセットウエストでのヘルシンキ 宣言の改訂をも踏ま之、WFAS 倫理コードの改訂 作業を、今後進める予定である。

第 3 は、「(社)日本鍼炎師会倫理綱領」である。 上述した文献にもこの作成プロセスが述べられて いるが、WFAS 倫理コードの作成と並行して、日 本で厚生省とも話し合いがなされて、1987年 4 月 1 日に制定されたものである。つまり、WFAS 倫 理コードより半年程早く制定された。

医学関係の専門家集団による倫理コード (professional code)には、世界医師会のジュネー ブ宣言（1948）や先のヘルシンキ宣言などのよう に医師全般が中心となったもの以外に、専門医と しての眼科医（1991）によるものなどがある。ま た非医師によるものとして、看護婦 (1953) やオ ステオパシー（1965）によるものがあるが、この 日本鍼炎師会によるコードは、鍼の領域では世界 でも初期のものに属し、設立年の早さと、その内 容とともに、世界に誇れるものである。この倫理 コードは、(社) 日本銊炎師会の名簿の第 1 頁に常 に掲載されている。 


\section{WORLD MEDICAL ASSOCIATION DECLARATION OF HELSINKI}

Recommendations guiding physicians in biomedical research involving human subjects

Adopted by the 18th World Medical Assembly

Helsinki, Finland, June 1964

and amended by the

29th World Medical Assembly, Tokyo, Japan, October 1975

35th World Medical Assembly, Venice, Italy, October 1983

41st World Medical Assembly, Hong Kong, September 1989

and the

48th General Assembly,

Somerset West, Republic of South Africa, October 1996

\section{INTRODUCTION}

It is the mission of the physician to safeguard the health of the people. His or her knowledge and conscience are dedicated to the fulfillment of this mission.

The Declaration of Geneva of the World Medical Association binds the physician with the words, "The Health of my patient will be my first consideration," and the International Code of Medical Ethics declares that, "A physician shall act only in the patient's interest when providing medical care which might have the effect of weakening the physical and mental condition of the patient."

The purpose of biomedical research involving human subjects must be to improve diagnostic, therapeutic and prophylactic procedures and the understanding of theaetiology and pathogenesis of disease.

In current medical practice most diagnostic, therapeutic or prophylactic procedures involve hazards. This applies especially to biomedical research.

Medical progress is based on research which ultimately must rest in part on experimentation involving human subjects.

In the field of biomedical research a fundamental distinction must be recognized between medical research in which the aim is essentially diagnostic or therapeutic for a patient, and medical research, the essential object of which is purely scientific and without implying direct 
diagnostic or therapeutic value to the person subjected to the research.

Special caution must be exercised in the conduct of research which may affect the environment, and the welfare of animals used for research must be respected.

Because it is essential that the results of laboratory experiments be applied to human beings to further scientific knowledge and to help suffering humanity, the World Medical Association has prepared the following recommendations as a guide to every physician in biomedical research involving human subjects. They should be kept under review in the future. It must be stressed that the standards as drafted are only a guide to physicians all over the world. Physicians are not relieved from criminal, civil and ethical responsibilities under the lawsof their own countries.

\section{BASIC PRINCIPLES}

1. Biomedical research involving human subjects must conform to generally accepted scientific principles and should be based on adequately performed laboratory and animal experimentation and on a thorough knowledge of the scientific literature.

2. The design and performance of each experimental procedure involving human subjects should be clearly formulated in an experimental protocol which should be transmitted for consideration, comment and guidance to a specially appointed committee independent of the investigator and the sponsor provided that this independent committee is in conformity with the laws and regulations of the country in which the research experiment is performed.

3. Biomedical research involving human subjects should be conducted only by scientifically qualified persons and under the supervision of a clinically competent medical person. The responsibility for the human subject must always rest with a medically qualified person and never rest on the subject of the research, even though the subject has given his or her consent.

4. Biomedical research involving human subjects cannot legitimately be carried out unless the importance of the objective is in proportion to the inherent risk to the subject.

5. Every biomedical research project involving human subjects should be preceded by careful assessment of predictable risks in comparison with foreseable benefits to the subject or to others. Concern for the interests of the subject must always prevail over the interests of science and society.

6. The right of the research subject to safeguard his or her integrity must always be respected. Every precaution should be taken to respect the privacy of the subject and to minimize 
the impact of the study on the subject's physical and mental integrity and on the personality of the subject. 7. Physicians should abstain from engaging in research projects involving human subjects unless they are satisfied that the hazards involved are believed to be predictable. Physicians should cease any investigation if the hazards are found to outweigh the potential benefits.

8. In publication of the results of his or her research, the physician is obliged to preserve the accuracy of the results. Reports of experimentation not in accordance with the principles laid down in this Declaration should not be accepted for publication.

9. In any research on human beings, each potential subject must be adequately informedof the aims, methods, anticipated benefits and potential hazards of the study and the discomfort it may entail. He or she should be informed that he or she is at liberty to abstain from participation in the study and that he or she is free to withdraw his or her consent to participation at any time. The physician should then obtain the subject's freelygiven informed consent, preferably in writing.

10. When obtaining informed consent for the research project the physician should be particularity cautious if the subject is in a dependent relationship to him or her or may consent under duress. In that case the informed consent should be obtained by aphysician who is not engaged In the investigation and who is completely independent of this official relationship,

11. In case of legal incompetence, informed consent should be obtained from the legal guardian in accordance with national legislation. Where physical or mental incapacity makes it impossible to obtain informed consent, or when the subject is a minor, permission from the responsible relative replaces that of the subject in accordance with national legislation.

Whenever the minor child is in fact able to give a consent, the minor's consent must be obtained in addition to the consent of the minor's legal guardian.

12. The research protocol should always contain a statement of the ethical considerations involved and should indicate that the principles enunciated in the present Declaration are complied with.

\section{MEDICAL RESEARCH COMBINED WITH PROFESSIONAL CARE (Clinical Research)}

1. In the treatment of the sick person, the physician must be free to use a new diagnostic and therapeutic measure, ifin his or her judgement it offers hope of saving life, reestablishing health or alleviating suffering. 
2. The potential benefits, hazards and discomfort of a new method should be weighed against the advantages of the best current diagnostic and therapeutic methods. 3 . In any medical study, every patient-including those of a control group, if any-should be assured of the best proven diagnostic and therapeutic method. This does not exclude the use of inert placebo in studies where no proven diagnostic or therapeutic method exists.

4. The refusalof the patient to participate in a study must never interfere with the physicianpatient relationship,

5. If the physician considers it essential not to obtain informed consent, the specific reasons for this proposal should be stated in the experimental protocol for transmission to the independent committee (I, 2).

6. The physician can combine medical research with professional care, the objective being the acquisition of new medical knowledge, only to the extent that medical research is justified by its potential diagnostic or therapeutic value for the patient.

\section{NON-THERAPEUTIC BIOMEDICAL RESEARCH INVOLVING HUMAN SUBJECTS (Non-Clinical Biomedical Research)}

1. In the purely scientific application of medical research carried out on a human being, it is the duty of the physician to remain the protector of the life and health of that person on whom biomedical research is being carried out.

2. The subject should be volunteers-either healthy persons or patients for whom the experimental design is not related to the patient's illness.

3. The investigator or the investigating team should discontinue the research if in his/her or their judgement it may, if continued, be harmful to the individual.

4. In research on man, the interest of science and society should never take precedence over considerations related to the wellbeing of the subject. 


\section{ヘルシンキ宣言}

ヒトを対象とする医生物学的研究に携わる医師に対する勧告

1964年 6 月、フィンランド、ヘルシンキの第18回 WMA 総会で採択

1975年10月、東京の第29回 WMA 総会で修正

1983年10月、イタリア、ベニスの第35回 WMA 総会で修正

1989年 9 月、香港、九龍の第41回 WMA 総会で修正

1996年10月、南アフリカ共和国、サマーセットウエストの第48回総会で修正

\section{緒 言}

人々の健康を守ることが医師の使命である。医師は、この使命達成のために、自分の知識と良心を捧げ るべきである。

WMAのジュネーブ宣言は、「私の患者の健康を私の第一の関心事とする」という言葉で医師に義務を負 わせている。また、医の国際的倫理基準では、「医師は、患者の身体的および精神的な状態を弱める影響 をもつ可能性のある医療に際しては、患者の利益のためにのみ行動すべきである」と宣言している。

ヒトを対象とする医生物学的研究は、診断、治療および予防の方法の改善と、病気の原因および病因に ついての理解を目的としなければならない。

今日の医療においては、大部分の診断的、治療的または子防的な方法は、何らかの危険を伴う。このこ とは、特に医生物学的研究の場合にあてはまる。

医学の進歩は研究に基づくが、この研究は、最終的にはヒトを対象とした実験に部分的に依存せざるを 得ない。

ヒトを対象とする医生物学的研究の分野では、目的が本質的に患者のための診断あるいは治療のためで ある医学的研究と、その本質的目的が純粋に学術的であって、研究の対象となる七トにとっては診断ま た治療において直接的価值のない医学的研究との間には、根本的な区別を認めなければならない。

環境に影響を及ぼす可能性のある研究の管理と実施においては、特別の注意が必要であり、また研究に 用いる動物の愛護も尊重されなければならない。

実験室内での研究の成果を人類に応用することは、科学的知識を深め、人類の恼みを救うということが 本質であるので、WMAは、ヒトを対象とする医生物学的研究に携わるすべての医師の指針として、次 のような勧告を用意した。これらの勧告は、今後も引き続き検討されなければならない。ここに素案と して提示した基準は、全世界の医師にとっての指針のひとつにすぎないことが強調されなければならな い。医師は、自国の法律のもとにおける、刑事、民事および倫理上の責任を免れない。 


\section{I 。基本原則}

1.ヒトを対象とする医生物学的研究は、一般的に受け入れられている科学的原則に従い、適切に行わ れた研究室における実験、動物実験ならびに科学文献による完全な知識に基づくものでなければな らない。

2．ヒトを対象とする個々の研究の計画および実施は、実験計画書に明確に記載され、この実験計画書 は、研究実施者および責任をもったスポンサーから独立した、特別に任命された委員会に提出され、 検討、コメントおよび指導を受けなければならない。ただし、この独立した委員会は、研究が実施 される国の法律、規則に従っていなければならない。

3. ヒトを対象とする医生物学的研究は、科学的資格をもつ人によって、臨床的に能力のある医療担当 者の監督のもとにおいてのみ行われなければならない。研究の対象である七トに対する責任は、常 に医学的資格を有する者にあり、たとえその研究の被験者の同意があったとしても、その被験者に は決して責任はない。

4.ヒトを対象とする医生物学的研究は、その研究の重要性を被験者に起こり得るリスクと比較考慮し たうえでなければ、合法的に行うことはできない。

5.すべての医生物学的研究は、被験者または他の人々に対して、予知できる利益と予想できるリスク を比較考慮しなければならない。被験者の利益に対する考慮は、常に科学的、社会的利益よりも優 先しなければならない。

6. 被験者が自分の人格のすべてを守る権利は、常に尊重されなければならない。被験者のプライバシー を尊重し、その身体、精神の両面にわたる本来のすがた、およびその人格に対して研究が与える影 響を最小限に留めるためには、あらゆる予防手段を講じなければならない。

7. 医師は、ヒトを対象とする研究において、自信をもって危険性を予知できる場合以外は、研究を行 うことを差し控えるべきである。起りうる利益よりも危険性が大きいということが分かった場合は、 医師はいかなる研究も中止すべきである。

8. 研究成果の発表に際しては、医師は結果の正確性を守る義務がある。発表のために、この宣言にも られている原則に従っていない研究の報告を受け入れてはならない。

9.ヒトを対象とする研究においては、被験者は、その研究の目的、方法、予想される利益と、研究が もたらすかもしれない危険性および不快さについて十分な情報を与えられなければならない。被験 者は、この研究への参加を断る自由をもち、参加していても、いつでもその同意を撤回する自由が あるという情報を与えられなければならない。そのうえで、医師は被験者の自由意志によるインフォー ムド・コンセントを、望ましくは書面で入手すべきである。

10. 被験者からインフォームド・コンセントを得る際に、医師は、被験者がその医師に依存した関係に ある場合、または強制されて同意することのある場合は特に注意しなければならない。このような 
場合、インフォームド・コンセントは、この研究に携わっていない、しかも上に記した両者の正式 関係には全く関与していない医師によって得られなければならない。

11. 法的無能力者の場合は、インフォームド・コンセントは、その国の法律に従って、法的保護者から 入手すべきである。被験者が身体的精神的無能力者、あるいは未成年者であるため、インフォーム ド・コンセントを得ることが不可能な場合は、その国の法律に従って、責任ある親族による許可が 被験者による許可の代わりになる。実際に、未成年者から同意を得られる場合は、未成年者の法的 保護者からの同意を入手する以外に、未成年者からも同意を得なければならない。

12. 研究計画書には、この宣言に明言されている倫理的配慮が常に含まれていなければならず、またこ の計画書は、この宣言にある基本的原則に従うものであることを明示しなければならない。

\section{II. 専門職としてのケアと結びついた医学研究（臨床研究）}

1.病人の治療に際して、新しい診断法や治療法が生命の救助、健康の回復、または苦悩の軽減になる と医師が判断した場合は、それを自由に用いるようにしなければならない。

2. 新しい方法により、起こる可能性のある効果、危険性、および不快さを、現行の最良の診断法およ び治療法による利点と十分比較検討しなければならない。

3.いかなる医学研究においても、どの患者も一対照群があればそれを含めて一現行の最善と証明され ている診断法および治療法を受けることができるという保証が与えられなければならない。これは、 立証された診断法あるいは治療法が存在しない場合の研究における無作用プラシーボの使用を除外 するものではない。

4. 患者が研究に参加することを拒否することによって、患者対医師の関係は決して妨げられてはなら ない。

5. 医師がインフォームド・コンセントをとらないことが本質的であると考える場合は、その決定に関 する特別な理由をの基本原則の第2項に述べてある独立した委員会に伝えるため、実験計画書にその ことを明記しなければならない。

6. 医師は、新しい医学知識を得るという目的をもって、臨床研究を専門職としてのケアと結びつける ことができる。しかしこの場合、この研究が許されるのは、患者に対して診断および治療において 価值があるという可能性のゆえに正当化される場合に限られる。

\section{III. ヒトを対象とした非治療的医生物学的研究（非臨床的医生物学的研究）}

1. 医学研究をヒトに対し純粋に科学的に応用する場合には、その医生物学的研究が実施されている被 験者の生命および健康の擁護者となることが医師の義務である。

2. 被験者は、健康な人か、または患者で実験計画がその患者の病気と関係のない場合、自発的意志に 
より研究に参加するものでなければならない。

3. 研究者あるいは研究チームは、研究を続けることが被験者に有害になると判断すれば、それを中止 すべきである。

4.ヒトを対象とした研究において、被験者の福利に対する配慮よりも、科学的、社会的な利益を決し て優先させてはならない。

(本ヘルシンキ宣言日本語版は日本医師会・国際課の試訳による。 日本医師会のご好意によりフロッピーで提供をうけ印刷した） 


\section{CODE OF ETHICS OF THE WORLD FEDERATION OF ACUPUNCTURE-MOXIBUSTION SOCIETIES (WFAS)}

The follwing ethical principles were adopted by the First General Assembly of the World Federation of Acupuncture-Moxibustion Societies (WFAS) at Beijing, China on 22 November 1987, and should be observed by every person who belongs to the member societies of WFAS.

1. Promise to dedicate one's effort to the service of the mankind.

2. Place one's knowledge and conscience in the service of one's profession.

3. Always maintain pride and sense of responsibility in one's profession; to inherit and propagate its honourable traditions.

4. Consider the health of one's patients as the first priority and also respect the confidentiality.

5. Administer acupuncture only when indicated, and in cooperation with professionals from other kinds of medical practices, one should aim to avoid administering inappropriate or unnecessary treatment.

6 . Never swerve from one's duty because of religious, national, ethnic, political or social reasons.

7. Never take advantage of the name of WFAS or of one's relationsship with WFAS for personal gain or for purposes of any commercial advertisement.

8. Strive to maintain the highest standards of professional conduct in acupuncturemoxibustion while constantly exploring its application in the study of human physiological and pathological processes.

9. Respect our professional colleagues and promote the solidarity of the profession. Improve the legal recognition and the medical status of acupuncture and moxibustion through its therapeutic usefulness and supportive results from scientific researches.

10. Respect the Declaration of Helsinki (adopted in Helsinki, 1964, amended in Tokyo, 1975 and in Venice, 1983) as far as biomedical research involving human subjects are concerned. 


\section{世界鍼炎学会連合会倫理コード}

以下の倫理的原則は、1987年11月22日に中国・北京での世界鍼炎学会連合会 (WFAS) 設立総会において採択された。WFAS 加盟学協会に所属するすべての人々によって遵守 されるべきものである。

1。人類への奉仕に捧げることを誓う。

2．自己の職務遂行にあたり自らの知識と良心とを捧げる。

3．自己の職責に誇りと責任を持ち、名誉ある鍼炎の伝統を守り、その発展に努力する。

4，自己の患者の健康を第一義としその秘密を守る。

5。適応時のみ鋮炎を行い、また他の分野の医療職との協調のもとに、不適切でまた価值のない治療を しないように努める。

6、決して、宗教、国籍、人種、政治的、社会的理由によって、患者に果たすべき義務を変えない。

7. 自らの利益や、いかなる商業宣伝の目的にも、WFASの名前やWFAS との関係を利用しない。

8. 常に人体の生理学的・病理学的プロセスにおける、鍼炎の適応を探り、たえず鍼炎について最高の 水準を保つことに努める。

9.プロとしての同僚を尊敬し、治療的有用性や科学的研究によって支持される成果を通し、法的認知 と鍼炎の医学的地位の向上に努める。

10.ヒ卜を含む生物医学的研究に関しては、へルシンキ宣言（1964年ヘルシンキに扔いて採択、1975年 東京、1983年べニスに扔いて修正）を遵守する。

〈津谷喜一郎・黒須幸男訳〉

（(訳注）第10項のヘルシンキ宣言は、その後1989年に香港、1996年に南アフリカ共和国のサマーセッ トウエストでさらに修正されている) 


\section{社団法人 日本鍼炎師会倫理綱領}

日本銊炎師会会員の遵守すべき倫理綱領を次のように定める

1. 私は生涯を人類への奉仕に捧げることを誓う

2，私は常に患者の健康の回復と保持増進を第一に考える

3．私は患者の信頼に応えて秘密を厳守する

4. 私は良心と誠意をもって治療に専念する

5. 私はたえず銊炎の学と術について最高の水準を保ち疾病に関する知識を一層樑め 伝統を守り その伝承に努力する

6、私は銊炎治療の有効性を高めその学術的研究の業績を重ねることによって他の医療分野から信頼 と協調を確保し患者の治療に努力する

7．私は銊炎治療の適応を十分認識し＼cjkstart無効な治療を行うことなく 更に過誤を犯すことのないよう に努める

8、私は常に自己の職責に誇りと責任をもち 鍼炎師としての名誉と尊厳をもって鍼尒の発展に努力 する

9. 私は治療に当って宗教 国籍 人種 政党 社会的地位の違いによって患者に果すべき義務を変 えることはしない

10. 私は流派を超えて相互に鍼尒師を尊重し 銊尒界の団結を高め 鍼尒師の資質向上のために努力 する

（掲載は(社)日本鍼炎師会のご好意による）

（(注）本倫理綱領には制定年月日が入っていないが、1987年 4 月 1 日に制定されたものである) 